\title{
Acts 8: 4-25: The Amazing Magic versus The Joyful Gospel
}

\author{
Chandra $\operatorname{Han}^{1) *}$ \\ 1) Universitas Pelita Harapan, Indonesia \\ *) Correspondent author: chandra.han@uph.edu
}

Received: 24 November 2020/ Accepted: 26 March 2021/ Published: 01 April 2021

\begin{abstract}
Magic as one significant theme in the Acts of the Apostles is not yet significantly exposed. In the Greco-Roman era, magic had become a part of people's lives from the lowest to the highest status, such as the Roman Emperor. The confrontation between magic which is likely amazing, with the joyful gospel is essential to be examined. The gospel's victory over magic is prominent for Christians and Church ministry because the power of the gospel that overcomes magic is the anchor of Christianity. This article will employ the literature research method within the qualitative research category. The most extended episode of the magical passage, Acts 8: 4-25, will be examined to figure out the distinctive feature between magic and the gospel and how the gospel overcome magic and the gospel is then widely spread throughout the region of Samaria and even to the end of the world. The literal translation and the text variant will be the first part of the examination. The following study is to demonstrate the structure. The next part is the exegesis to figure out the meaning of the text within the relevant context, including the distinction between magic and Christianity. The last part is the Implications within the contemporary era for Christians and Church ministry and conclusion.
\end{abstract}

Keywords: Acts of the Apostles, Church ministry, Gospel, joy, magic

\section{Abstrak}

Sihir sebagai salah satu tema penting dalam Kisah Para Rasul yang belum terungkap secara signifikan. Di era Yunani-Romawi, sihir telah menjadi bagian dari kehidupan masyarakat dari yang berstatus paling rendah hingga yang tertinggi, seperti Kaisar Romawi. Konfrontasi antara sihir yang mungkin menakjubkan, dengan Injil yang menggembirakan itu penting untuk diperiksa. Kemenangan Injil atas sihir menonjol bagi orang Kristen dan pelayanan Gereja karena kekuatan Injil yang mengalahkan sihir adalah sauh Kekristenan. Artikel ini akan menggunakan metode penelitian kepustakaan dalam kategori penelitian kualitatif. Episode paling panjang dari bagian sihir dalam Kisah Para Rasul 8: 4-25, akan diperiksa untuk mengetahui ciri khas antara sihir dan Injil dan bagaimana Injil mengatasi sihir dan Injil kemudian tersebar luas di seluruh wilayah Samaria dan bahkan sampai ke ujung dunia. Terjemahan literal dan varian teks akan menjadi bagian pertama dari pemeriksaan. Studi berikut adalah untuk mendemonstrasikan strukturnya. Bagian selanjutnya adalah 
eksegesis untuk mencari tahu makna teks dalam konteks yang relevan, termasuk perbedaan antara sihir dan agama Kristen. Bagian terakhir adalah implikasi dalam era kontemporer bagi pelayanan dan kesimpulan umat Kristen dan Gereja.

Kata-kata Kunci: Kisah Para Rasul, Pelayanan Gereja, Injil, Sukacita, Sihir

\section{Introduction}

Simon Magus's account is the most famous passage in understanding magic ${ }^{1}$ for several considerations: First, this is the initial confrontation with magic where Luke introduces the conflict between the Gospel and magical practices. Second, this is the lengthiest account regarding magic. Third, Simon, the magician, is reported as an inhabitant of Samaria, and Jesus himself mandated and commissioned his disciples to travel to the city for mission work in Acts 1:8. This is not to say that other cities are not necessary, but perhaps the success of the mission in Samaria will serve as an affirmation that the command to be witnesses of Jesus to the end of the world will be successful as well. Such a lengthy account of the magician Simon in a city unrenowned with magic may indicate that this passage can carry out the understanding of magic as a representative. Fourth, magician Simon's massive influence with his magic is also important since he becomes a prominent representative to the power of magic with massive personal influence even in the capital city of Rome. Fifth, this section allows Luke to describe the difference between demonic magic and godly miracles.

The most significant question is how wicked is the amazing magic that it must be vanquished through confrontation with the gospel? This article will demonstrate that though it is amazing, indeed magic is

${ }^{1}$ The attention of this passage has frequently emphasized more the sources Luke used to compose. Since this chapter will examine Simon as the primary example of magic, the issue of source will be addressed only when it is related significantly to the discussion. Not only is the examination of source speculative but also the relevance to the intention of Luke in presenting the episode less important compared to the confrontation between Philip, Peter, and Simon, the magician. See for instance C. K. Barrett, The Acts of the Apostles ICC, vol. I (Edinburgh: T \& T Clark, 1994), 396, and Gerd Lüdemann, Early Christianity according to the Tradition in Acts: A Commentary (Minneapolis: Fortress Press, 1989), 94-7. For a brief yet helpful discussion on source, see Haar, Simon Magus, 73-6. For a more comprehensive discussion see Jacques Dupont, The Sources of Acts: The Present Position, translated by Kathleen Pond (London: Darton, Longman \& Todd, 1964). 
seriously wicked (as obviously represented in Simon Magus, the magician) and it must be overcome by the gospel through confrontation only, so then the gospel can be proclaimed freely. The passage in this article will be examined into four sections with the grammatical examination of each section followed by the exegesis of each section as well. In conclusion a table that shows the contrast between magic and the power of the gospel with the victory of the gospel, is provided. The last part is the implication of this exegesis for church ministry.

\section{Theory}

Theoretically, magic is negative, particularly for Christianity although, it is possitive for the Roman authority.2 However, this passage's comprehensive study, particularly the spiritual aspects manifested in the phenomena, has not yet been examined. The work of Tarundeep, who discussed religious conviction, mysticism and wellbeing ${ }^{3}$ is still lack of examining joy, a significant phenomenon of spiritual manifestation, which is examined in this article. Kent's article of curses in the Acts of the Apostles did present the negative side of cursing but failed to examine joy as a contrast to cursing. ${ }^{4}$ Tony Burke's work is focused on cursing, and the apostles with the relation of the fighting for authority ${ }^{5}$ still miss to examine the joy. In the pastoral aspect, Rahel Jum Juld and I Ketut Enoh examined more on the occultism $^{6}$ and demonstrated less on the joy, which is the centre of the gospel. Thus, it is important to examine Acts 8:4-25 to comprehend the victory of gospel and magic fully.

${ }^{2}$ Chandra Han, "Magic in Greco Roman Era: A Historical Context for Magic in the Acts of the Apostles," Jurnal Jaffray 18, No. 1 (April 2020): 24-5.

3 Tarundeep, "Remedial Theology: An exploration into the factors-Religious conviction, mysticism, and wellbeing," Scholedge International Journal of Multidisciplinary and Applied Studies 2, no. 9 (2015): 11-6.

${ }^{4}$ Benedict H. M. Kent, "Curses in Acts: Hearing the Apostles' Words of Judgment Alongside 'Magical' Spell Texts," Journal for the Study of the New Testament 39, no. 4 (2017): 412-440.

5 Tony Burke, "Cursing and the Apostle: The Fighting for Authority in Early Christianity," Forum, Third Series 8, No. 2 (2019): 81-107.

${ }^{6}$ Rahel Jum Juld and I Ketut Enoh, "Okultisme dalam Pelayanan Pastoral," Jurnal Jaffray ll, no. 2 (October 2013): 165-190. 


\section{Method}

The method used in this article is literature study within the category of qualitative research. ${ }^{7}$ The literature relevant to the text such as articles, books, and the translation of the Greek Magical Papyri will be employed and appropriately addressed. ${ }^{8}$ There are three steps in examining this article. The first step is to translate the text directly from the Greek text which is the primary source, followed by analyzing the text variant. The second step is to analyze the Greek grammar to propose the structure. The third step is the exegesis of the text with the support of the relevant historical background. Many scholars's commentary, which are secondary sources on the text will be analyzed to demonstrate the clear and comprehensive summary. Finally, is the implication for church ministry and conclusion.

\section{Result and Discussion}

The discussion section will examine the structure, the grammatical, exegesis of the passage to figure out the meaning, then finally provide the conclusion to demonstrate the contrast between magic and gospel in the context of proclaiming the victory of the good news over magic to the end of the world.

\section{The Structure}

This lengthy passage will be divided into four sections ${ }^{9}$ for examination: first, the section that deals with Philip in Acts 8:4-8; second, the section that presents Simon as in Acts 8:9-13; third, the section that describes the sending of Peter and John and the significance of the Holy Spirit found in Acts 8:14-17; and the fourth section that discloses the confrontation of Peter and Simon covering Acts 8:18-24. The conclusion in verse 25 creates an inclusion with the introductory section in verses $1 b-3$.

7 See John W. Creswell, Educational Research: Planning, Conducting, and Evaluating Quantitative and Qualitative Research, $4^{\text {th }}$ ed. (Boston, MA: Pearson Education, 2002), 16.

${ }^{8}$ Creswell, Educational Research, 80.

${ }^{9}$ See Beverly Roberts Gaventa, The Acts of the Apostles (Nashville: Abingdon Press, 2003), 134-39, who also divided this passage into four sections that ended in verse 24; see also Barrett, The Acts of the Apostles, 398. 
Introduction: the scattering of believers into Judea and Samaria $(\mathrm{lb}-3)$

I A Philip and the power of Jesus' name (4-8)

II B Simon, the first wickedness of his magic, and his submission (9-

13)

III A' Peter and the power of the Holy Spirit (14-17)

IV B' Simon, the wickedness of his magic, his petition, (18-24)

Conclusion: the preaching of the gospel in many villages of the Samaritans (25)

The unit of Acts 8:4-24 is part of the larger unit of Acts 8:1b-25. Several features that bind this lengthy unit of Acts 8:1b-25 as one unit are: 1) the literary device "egeneto de"10 which is Lukan narrative style to mark a new section and at the same time further the progress of his narration; 2) the inclusion of Jerusalem and Samaria found in verse $\mathrm{lb}$ and verse $25 ; 3$ ) the change of the geographical location and the theme in the following passage of Acts 8:26-40. However, the passage of Acts 8:425 does evidence many features that hold it together as a single narrative. First, the pattern ABA'B' is prominent. Second, the lexical coherent of "Samaria" is found in verses 5, 8, 9, 14, 25. Third, the theme has moved from the persecution of believers found in verse $1 \mathrm{~b}-3$ to the confrontation with magic and the further spread of the gospel in all the cities of the Samaritans. Fourth, the figures in Acts 8:4-25 are specific to merely Philip, Simon, and Peter instead of "all" including Saul the persecutor in Acts 8:1b-3. Fifth, a further inclusion in the two accounts, the preaching of the gospel in verse 4 and verse 25, obviously binds this unit as one. Moreover, the precise phrase "therefore" found in verse 4 and 25 strongly suggests that Acts 8:4-25 can be examined as an independent unit within the larger unit.

\section{The Grammatical Examination}

The examination of the grammar will be done by section. In each case a literal translation will be given first so that the original Greek is transposed even though the English might sound wooden.

${ }^{10}$ For the general function of this phrase "egeneto de" to indicate the progress of the narrative, see BAGD, 159. 
The Literal Translation of Section I, Acts 8:4-8

4) Therefore those who were scattered, they went through preaching ${ }^{11}$ the word ${ }^{12}$ 5) and Philip, going down into the ${ }^{13}$ city of Samaria, kept on proclaiming ${ }^{14}$ to them the Christ 6) and paying attention were the crowd ${ }^{15}$ to the word continue to be said ${ }^{16}$ by Philip with one accord when ${ }^{17}$ they hear and see the signs he was doing ${ }^{18} 7$ ) for many of those who were having the unclean spirits shouting ${ }^{19}$ with a great voice they were coming out, ${ }^{20}$ and many who had been paralyzed ${ }^{21}$ also lame they were healed 8 ) and there existed ${ }^{22}$ much joy in that city.

${ }^{11}$ The Greek word "euangelizomenoi" literally means "preaching the good news." The conjugation of this word is present participle middle nominative masculine plural, and it carries the aspect of continuation action of preaching the good news. The phrase "the good news" is omitted because of the redundancy in English.

${ }^{12}$ The addition of "tou theou" (of God) is found in $\mathrm{E} \mathrm{p}^{\mathrm{c}} \mathrm{t} \mathrm{w} \mathrm{vg}^{\mathrm{cl}} \mathrm{syp}^{\mathrm{p}} \mathrm{bo}^{\mathrm{mss}}$, but it does not influence the whole passage's meaning. Either "the word of God" or "Lord" is basically the same since both carry the identical understanding, the word about Jesus Christ, the Lord.

${ }^{13}$ The addition of this article "ten" is recorded in C D E Y 33. $1739 \mathrm{M} \mid$ txt $\mathrm{P}^{74}$ a A B $1175 \mathrm{pc}$. With such support, the presence of the article is maintained. The impact of this article to understand which city of Samaria is referred is disputed among scholars. See the following discussion under the title "The Exegesis".

14 The Greek word "ekêrussen" is in the imperfect tense. This means that the emphasis is on the continuation of action in the past.

15 This is the Greek arrangement of the sentence. The verb is placed before the subject "the crowd" while the adverb "with one accord is put after "Philip". The tense of the verb "were paying attention" is imperfect that emphasizes on the continuous action in the past.

${ }^{16}$ The translation as such is to demonstrate the present participle passive dative plural "legomenois" used in the Greek text.

17 The time "when" is expressed by Luke by using the articular infinitive of the dative, which is the combination of preposition "en", the dative article "to" with two infinitives "akouein" and "blepein", while the subject is the accusative "autous."

${ }^{18}$ The tense of the verb "was doing" is imperfect. Thus, Philips consistently performs signs and not just once.

19 The Greek word is "boônta" which is present participle accusative neutral plural. This accusative neutral plural of the participle is the same as the accusative neutral plural of the noun "unclean spirit".

${ }^{20}$ For the right arrangement of this clause see the discussion under the title "The Grammatical examination of section I" in the following.

${ }^{21}$ This is the perfect participle passive of Greek "paralelumenoi"; the passive mood implies that such a paralyzed one does not occur naturally but is likely caused by powers other than God.

22 Though the formula "egeneto de" is the same as the one in verse $\mathrm{lb}$, this formula does not share the same function as a mark of a new section in the narration. It is likely that here, the consequences of Philip's deeds are concluded. 


\section{The Grammatical Examination of Section I}

Four grammatical examinations are addressed in this first section. First, the particle "therefore" (oun) found in verse 4 functions both as the conclusion of the previous section about the persecution of believers and at the same time presents the consequences in the following section. The main clause is "they went through". ${ }^{23}$ Second, the using of imperfect tense of the verb in verse $5^{24}$ confirms that those who are scattered including Philip keep on preaching the good news. The city Philip keeps on preaching is explicated by the participle phrase "going down into 25 the city of Samaria." Christ is the heart of Philip's proclamation. Luke in verse 5 has narrowed the figure from those who are scattered to Philip with the consistent action of preaching the word just like those who are scattered.

Third, the paying attention of the people of Samaria presented in verse 6 is prominent. The adjectival participle "what that are said" explains that the people of Samaria are paying attention to Philip's message, Christ. The adverb "with one mind" is so essential for it shows how the people of Samaria pay attention and this adverb is not found when Luke depicts the paying attention of the people of Samaria to Simon in the following section II.

Fourth, at first sight, the order of the clause in verse 7 seems unusual, but this unusual order can be clarified with a careful examination. The particle "because/for" provides an explanation of what Philip has done in previous verse 6 . Two negative features need to be resolved. The first is "those who had unclean spirit." 26 The second phenomenon is the healing of the lame and paralyzed. The verb's tense is "be healed" (etherapeuthêsan) which indicates the healing has indeed

${ }^{23}$ The tense of the main verb is aorist indicative but more important is the present participle used to explain the verb "went through" and the subject of the verb "went through" is explicated by using a participle, "those who were scattered," which implies many places rather than just one.

${ }^{24}$ The focus of this verse 5 is Philip. The main verb is "kept on preaching", and the tense is Imperfect that emphasizes on the aspect of repetitive action which is identical to the same aspect of the word "preaching" in verse 4

25 That Philip goes inside the city (and not near the city) is clear by using preposition "eis" combined with accusative.

${ }^{26}$ It can also be translated as such: "Those who have the unclean spirits they (these spirits) kept on coming out shouting with a great voice." since the tense of the participle is present. The subject of the verb "kept on coming out" is clearly the unclean spirits rather than the person possessed. 
happened. ${ }^{27}$ The result of Philip's ministry is surprising and concluded by Luke in verse 8 as "And there existed much joy in that city."

The first section summarises that Philip, one of the scattered believers, goes down to Samaria and consistently preaches the message of Christ as other believers do. Philip's proclamation comes along with the signs he performed and gains the attention of the people of Samaria. The result of Philip's ministry is extraordinarily positive since joy existed in the city.

\section{The Literal Translation of Section II, Acts 8: 9-13}

9) now a certain man, in name Simon who used to exist before ${ }^{28}$ in the city keeps on practising magic ${ }^{29}$ and amazing the nation of Samaria saying (in respect of) himself to be ${ }^{30}$ someone great 10) to whom paying attention were all from the small until the great saying "This man is the power of God which is being called ${ }^{31}$ great" 11 ) and they kept on paying attention to him because ${ }^{32}$ in a sufficient time they have amazed to the magic deeds 12) but when they believed Philip preaching (good news) concerning the kingdom of God and the name of Jesus, they were baptized men and also women 13) and also Simon himself believed and

${ }^{27}$ See William D. Mounce, Basics of Biblical Greek $3^{\text {rd }}$ ed. (Grand Rapids: Zondervan, 2009), 201-3 who presents the meaning of aorist tense that depends much on the context. The meaning of aorist can be ingressive (to begin an action) or proleptic (describing the action in future) or gnomic (a timeless truth) or constative (describes the action as a whole without explaining the nature of the action). However, there is one certain meaning of aorist that the action has indeed happened although it tells nothing about the action of the verb (undefined). The constative and the undefined meaning of aorist is likely the case here. See also Daniel B. Wallace, The Basics of New Testament Syntax: An Intermediate Greek Grammar (Grand Rapids: Zondervan, 2000), 23943.

28 The translation is presented to express the imperfect tense of the verb "proupêrchen" which means it existed before.

29 The present participle active "mageuôn" suggests a continuous action of performing magic is used by Luke. The verb "mageuo", magician (magos) and magic (mageia) share the same root.

30 The structure of the clause is somewhat awkward, although the meaning is obvious enough that Simon himself claims to be someone great.

${ }^{31}$ Such a translation is intended to show the present participle passive of "he kaloumene" in the Greek text.

32 The causal conjunction in this verse employs the articular infinitive introduced by a preposition "dia" instead of a particle "gar" or "hoti". The formula is constituted by the combination of preposition "dia" and the accusative of the articular infinitive "to ...... eksestakenai" with the accusative "autous" (they) as the subject. 
after being baptized he was attaching to Philip, looking at the signs and great power he kept on amazed.

\section{The Grammatical Examination of Section II}

The genitive found in the phrase "the power of God who is being called great" in verse 10 is complex. There are at least two possibilities to classify the genitive in "the power of God". One possibility is the genitive of apposition so that the meaning will be "the power which is God". Such a meaning is possible if the power is God, but this might not be true. ${ }^{33}$ Another possibility is the genitive of source or belonging, thus the meaning will be the power which is from (or belongs to) God. This meaning could be true particularly when Simon himself is understood as the power that is great and not that Simon is God. ${ }^{34}$ This latter sense is likely the meaning in the light of the previous verse 9.

There are at least six main clauses found in this section II. One lengthy clause is found in verse 9 , another one is in verse 11 , one is in verse 12 , and three in verse 13 . The primary concern of all these clauses is Simon and his role either in performing magic in his past or afterwards in believing, following, and being amazed by the signs performed by Philip. The lengthy main clause in verse 9 is identified with the main verb "used to exist before". Simon's role before the coming of Philip is disclosed by two participles "practicing magic" and "amazing", 35 to indicate that the magic performed by Simon is not a single spontaneous action but a consistent action of performing magic in Samaria. Another participle "saying" (legon) refers to Simon's claim "on himself to be someone great" (einai tina heauton megan). ${ }^{36}$ All these are strong evidence that Simon's claim to be great originated in his magic performance.

The grammatical examination of verse 10 is not simple, especially the last part. As for Philip, here the magical performance of Simon results

33 See Barrett, The Acts of the Apostles, 407.

${ }^{34}$ Ibid., 407.

35 The tense of both participles "practicing magic" (mageuôn) that explain Simon's deeds of magic and "amazing" (exsistanôn) is present that emphasizes the continuation of action.

36 See Mikeal C. Parsons, Acts Paideia Commentaries on The New Testament (Grand Rapids: Baker Academic, 2008), 115, who refers to A. T. Robertson, Word Pictures in the New Testament 3 vols. (New York: Harper and Brothers, 1930-1933) to suggest that the combination of the indefinite pronoun "tis" (someone) with an adjective is rhetorically emphatic and Ironic. 
in "proseichon", 37 the paying attention of the people of Samaria. The implication of the "paying attention" is the saying ${ }^{38}$ of the people to Simon that "This man is the power of God which is being called great". In Greek, the word "the power", "great" and the adjectival participle "he kaloumene" can be read as "which is being called the great power." Therefore, the whole saying of Samaria's people can be read alternatively "This man is which is being called the great power of God". ${ }^{39}$ Although both translations (this alternative translation and the translation given previously in section II) are grammatically right, but from the light of Simon's claim to be someone great in verse 9, the translation presented in the literal translation of section II is preferred.

Here in verse 1l, Luke provides the reason why Samaria's people kept on paying attention to Simon. ${ }^{40}$ It is interesting to notice that in the episode of Philip, Luke provides the temporal aspect explicitly ${ }^{41}$ to show the reason implicitly, while here in verse 11 Luke describes both time and reason explicitly. A surprising feature found in both verse 9 and verse 11 is the recurrence of "amaze" and "practicing magic" concurrently. Therefore, it is sensible to conclude that the amazement of Samaria's people is because of Simon practiced magic.

The figure of Philip in verse 12 is peculiar since the episode is basically about Simon. Therefore, the particle "de" is understood better as contrast than a transition. The conjunction "hote" (when) reveals the confrontation between Simon and Philip. The evidence is obvious in the change of the figure from Simon to Philip. Moreover, this verse 12 provides Philip's deeds and the positive response of the people of Samaria. In verse 12, the dative phrase "to philipo euangelidzomeno" is intriguing since there are several translations in English bibles. ${ }^{42}$ An

37 The tense of "proseichon" is imperfect which indicates that paying attention has continuously happened.

38 The tense of the participle "saying" in Greek is present which means that the saying of Samaria's people happens continuously rather than spontaneous action.

39 See New American Standard Bible (NASB); New International Version (NIV) Bible (TNIV as well) also shares the same translation with a slight change in the first phrase.

${ }^{40}$ Luke shrewdly uses the preposition "dia" combined with the accusative of the articular infinitive "to be amazed" (to ... exestakenai)

${ }^{41}$ Luke used the "in" with the dative of the articular infinitive with an implicit reason.

42 See for instance New English Translation; New International Version Bible; also Revised Standard Version. 
alternative translation "Philip who keeps on preaching" perhaps could fit better to the context. ${ }^{43}$ However, whichever translation is adopted, they both share the basic understanding that the people of Samaria believed in Philip's preaching.

In verse 13, the figure Simon returns to the drama but with an ironic twist that Simon who used to amaze the people of Samaria, now was surprised by Philip. The most significant is the combination of "Simon" and the "autos" denotes the emphasis on Simon, thus the meaning must be "Simon himself". Such an emphasis intensifies greater the irony of Simon in his confrontation with Philip.

This grammatical examination of section II indicates that Simon himself though he amazes Samaria's people with his magic for a long time and even claims himself as someone great, he is no rival to the power of God as reflected in Philip's proclamation of the gospel and miraculous performance. Yes, the text shows convincingly that Simon seems to believe and then he was baptized, but through a careful closer examination demonstrated previously, Simon's belief and baptism is basically a fraud since his only concern is on power and not on Jesus Christ whom Philip preached.

\section{The Literal Translation of Section III, Acts 8: 14-17}

14) and hearing the apostles in Jerusalem that Samaria had received the word of God, they sent ${ }^{44}$ to them Peter and John 15) who going down

${ }^{43}$ This dative phrase itself consists of three elements, a dative article, a noun, and a present participle. The key element to understand this phrase is the connection of the dative article. In most translations the article relates to Philip rather than the participle. In such a translation the participle is considered as a verbal participle and the translation is "as he preached the good news". This is understandable since Philip is a name used in the article. However, grammatically the article may link to the participle and the noun "Philip" may not need an article. The word "Philip" in all cases occurs four times in this passage Acts 8:4-25; they are in verse 5, 6, 12 and 13. Three occurrences of "Philip" carry an article, but there is one occurrence in verse 5 that does not have the article. There is one occurrence in this passage Acts 8:5 where the noun "Philip" does not have an article and thus the absence of an article to the noun "Philip" is possible. There can be other translation also. If the article belongs to participle, then the participle is an adjectival participle and the translation is "Philip, the one who keeps on preaching (the good news)" with "the one" refers to Philip, thus, the translation turns out to be "Philip who keeps on preaching (the good news)". This alternative translation that categorizes the participle as an adjectival participle seems to fit better with the context.

${ }^{44}$ The tense of this verb is aorist in Greek, which means one-time action in past time. The same tense is the verb "prayed" found in verse 15. 
prayed for them so that they may receive ${ }^{45}$ the Holy Spirit 16) because not yet ${ }^{46}$ it had fallen ${ }^{47}$ on anyone of them and only they had been baptized ${ }^{48}$ into the name of the Lord Jesus 17) then they kept on laying upon ${ }^{49}$ the hands on them and they kept on receiving the Holy Spirit.

\section{The Grammatical Examination of Section III}

Several grammatical details will be carried out in this section. First, the whole participle phrase in verse 14 that explicates the main verb "they sent" provides a significant detail of when and why Peter and John are sent. The second examination is on verse 16 and 17. The double negatives in verse 16, "oudepô" (not yet/still not) and "oudeni" 50 emphasize that the Holy Spirit indeed has not yet fallen upon the people of Samaria. The presence of "only" 51 is interesting since it can be an adjective or an adverb with a variety of meanings. This "only" is likely used as an adverb combined with the periphrastic formula of "have been baptized only" to denote a limiting action involved in the Samaritan's baptism..$^{52}$ What is lacking from baptism is uncertain. Both verbs "epetithesan" (kept on laying hand) and "elambanon" (kept on receiving) in verse 17 confirm the repetition of laying hand to receive the Holy Spirit. The conjunction "kai" here functions to introduce a result (the receiving of the Holy Spirit) which comes from Peter and John's laying on of hands. ${ }^{53}$

Section III demonstrates that although the people of Samaria have been baptized, they have not yet received the Holy Spirit. This is likely the reason to send Peter and John to Samaria and dispense the gift of

\footnotetext{
45 The addition of "may" is because the mood of the verb "labôsin" is a subjunctive that indicates a wish or an expectation. The tense itself is aorist.

${ }^{46}$ Literally, two negative "oudepô" (not yet) and "oudeni" (no one), appear in this formula, but in Greek, the two negatives will remain negative and never turn to positive as in English.

${ }^{47}$ The periphrastic pluperfect formula, the construction of the Imperfect "en" and perfect participle "epipeptôkos" is used here.

48 Another periphrastic pluperfect is employed here, although the imperfect "huperchon" is used instead of the imperfect of "eimi".

49 The translation is as such to maintain the aspect of the imperfect tense of the verb. The same case is applied to the verb "kept on receiving".

50 the dative case of an indefinite pronoun followed by a preposition "epi" to mean "upon no one"

${ }^{51}$ The meaning of this word as alone or isolated can be ruled out since it does not fit the context at all.

52 See BAGD, 528.

${ }^{53}$ Ibid., 392.
} 
God which is the Holy Spirit through prayer and by mean of the laying on of Peter's and John's hand. The episode of receiving the Holy Spirit may also anticipate the Holy Spirit's power (manifested implicitly in the rebuke of Peter) to reveal the wickedness of Simon's request for power and the evilness in his heart in the following section IV.

\section{The Literal Translation of Section IV, Acts 8: 18-25}

18) and Simon seeing ${ }^{54}$ that through the laying on of the hands of the Apostles is given the Spirit ${ }^{55}$, offered them money 19) saying "give me also this authority in order that on whom when I lay the hands one may receive $^{56}$ the Holy Spirit" 20) but Peter said to him "The silver of you together with you may (be) in destruction because the gift of God you supposed through the wealth to acquire 21) there is no part for you not even a portion in this word, for the heart of you is not right before God 22) therefore repent from this evil of you, ask of the Lord if then there will be forgiven you the intention of your heart 23) for into a gall of bitterness and a bond of unrighteousness I see that you are" 24) but answering Simon said "You, ${ }^{57}$ pray on behalf of me to the Lord in order that nothing may come (upon me which you have said) ${ }^{58}$ 25) Therefore they who testified solemnly and spoke the word of God continued to return to Jerusalem, and to many villages of the Samaritans they continued to preach the gospel.

\section{used.}

54 The translation is maintained as such to show that the participle "idon" is

55 The addition of "the Holy" ("to hagion") is found in a B copsa,meg; Most manuscripts such as P45, 74 A C D E Y 333681181307453610614945117514091678 173918912344 Byz put only "the spirit" (Pneuma). However, there is no significant impact to the meaning of the passage.

56 There are two possibilities to understand this phrase: one possibility is that this is a conditional sentence as identified by the using of "ean" and aorist subjunctive "epithô" in the protasis (the "if" clause) and present subjunctive "lambanê" in the apodosis (the "then" clause). The other possibility is to understand the "ean" as temporal to mean "when" or "whenever" and the subjunctive "lambanê" remains the expected consequence. Although both possibilities provide the similar basic understanding, the latter fits better to the context.

57 The addition of "you" (humeis) is emphatic since in Greek no pronoun is actually needed in the second person singular of aorist imperative "pray"; See also Barrett, The Acts of the Apostles, 416.

${ }^{58}$ This addition is found in $\mathrm{P}^{74}$ a A B Y 33368118130745361061494511751409 1678173918912344 Byz. 


\section{The Grammatical Examination of Section IV}

The first grammatical examination in this section IV involves verses 18 and 19 which are one sentence. The meaning of "idôn" (having seen) is not an apathetic seeing but a considerable and contemplative sense of seeing. ${ }^{59}$ Thus Simon is seriously putting his eyes on what happened. Interestingly, the prayer is missing from the scene. The tense of the main verb "offered" in this verse 18 emphasizes on the fact of Simon's offer. ${ }^{60}$ Simon wishes to buy "this authority" namely, the authority to dispense the Holy Spirit. Simon's offer confirms his magical principle that manipulates the divine beings and has authority over them.

The rebuke of Peter that takes three verses from verse 20 to 23 . Peter's rebuke also reveals much wickedness in Simon's character than merely addresses Simon's offer. The capability of Peter (who has never encountered with Simon before) to reveal Simons's wickedness even the invisible evilness implies the power of the Holy Spirit who empowers Peter. The rebuke is that Simon's money together with ${ }^{61}$ his person ${ }^{62}$ will suffer destruction. The phrase "into destruction" is not overstated since the "because" 63 indicates the reason why Peter rebukes Simon. The genitive "tou theou" 64 suggests that the Holy Spirit belongs to (or is) God and is also a gift given by God. Thus, there is absolutely no chance to buy such a gift as obvious in the meaning of "tên dôrean" which is a gift without payment. ${ }^{65}$

The third examination is in verse 21 . The double negative "ouk" (not) and "oude" (not even), and the two identical nouns "meris" (part) and "klêros" (portion) in verse 21 intensify the inability for Simon to take any part "in this word". The particle "gar" (because) explains why Simon never takes part in this word. The following phrase reveals that the heart

${ }^{59}$ See BAGD, 371.

${ }^{60}$ See Mounce, Basics of Biblical Greek, 201-2. The tense is aorist.

61 The preposition "sun" usually followed by a dative case denotes an accompaniment and association with someone; see BAGD, 781.

${ }^{62}$ Introduced by the preposition "sun" (with) with "soi" (you).

${ }^{63}$ Among three functions of "hoti", the mark of direct statement, the use as an indirect statement or dependent clause, and the causal use, the later causal use is likely the case here. Syntax, 56

${ }^{64}$ This can be a genitive of possession See Wallace, The Basics of New Testament ${ }^{65}$ See BAGD, 210. 
of Simon is not right. ${ }^{66}$ The shift of Peter's rebuke's object is obvious from Simon's thought (verse 20) to Simon's heart (verse 21).

The fourth grammatical examination is verse 22 and 23 . The last phrase of verse 22 is "if then the thought of the heart of you will be forgiven to you. The genitive "of the heart" 67 gives the meaning as "(the thought) that comes from the heart. In verse 23 there are two real conditions of Simon as expressed in "into a gall of bitterness and a bond of unrighteousness". Within the three meaning of the genitive "pikras" (bitterness) ${ }^{68}$ the genitive of quality and the genitive of content are preferable because both words "cholen" and "pikrias" basically share the same sense of bitterness, thus it is likely that this is to intensify the bitterness of Simon ${ }^{69}$ who was once honoured as the great one but now is rebuked. Consequently, the preposition "into" could no longer denote the destination, although in general its function is the same as the dative "en". 70

\section{The Exegesis}

The exegesis of this lengthy pericope will be taken by section rather than by verse. Since this chaptes intends to study magic as primarily represented in Simon, the exegesis will focus more on problems related to magic and not address all the issues within the scholarship discussion.

The formalized division into four sections has raised the question of the historicity of this passage. As is obvious from the pattern of the structure A (Philip) B (Negative image of Simon) A' (Peter) B' (A more negative image of Simon), the sharp distinction of figures and theme in such a pattern has led scholars ${ }^{71}$ to argue that Luke composed this

${ }^{66}$ The "eutheia" (right) is an adjective, the literal meaning is "of a way" but here the meaning is likely "right" as the opposite of wrong; See BAGD, 321.

${ }^{67}$ It can also be the attributive genitive to give the translation as the thinking heart, but this is not likely the case.

${ }^{6}$ The meaning can be bitterness (a genitive of material), full of bitterness (a genitive of content), "that makes bitterness" (an objective genitive), or in association with bitterness (a genitive of association), or the quality of the gal (the genitive of quality), see Wallace, The Basics of New Testament Syntax, 50-62.

${ }^{69}$ See Barrett, The Acts of the Apostles, 416-7.

70 Ibid., 416.

${ }^{71}$ See for instance Barret, in The Acts of the Apostles, 399; H. Conzelamann, The Acts of the Apostles: A Commentary on the Acts of the Apostles, trans. by J. Limburg, A. T. Kraabel, and Donald H. Juel (Philadelphia: Fortress Press, 1987), 62-6; also, Ernst Haenchen, The Acts of 
passage from literary sources. Various theories have been proposed to solve this issue, but no satisfactory theory has won the day. The question of why Luke places the account in Acts is more important than how many sources he may have used. Therefore, the discussion on the source will be ruled out from the sectional exegesis; instead, Acts' apologetic purpose will underlie the following discussion.

\section{Section I: Acts 8: 4-8}

Two significant features are found in section I. First, the primary character is Philip with all his miracle performances and his message. Second, the place is Samaria. Philip, one of the "seven" mentioned in Acts 6:1, is certainly one of "those who had been scattered" who went about preaching the word.

A dispute involves in which the city of Samaria Philip proclaims Christ. The presence or omission of the article "the" in the phrase "the city of Samaria"72 is critical to single out which city of Samaria does Philip really proclaim Christ. If the article is maintained, the city must refer to Samaria's main or the capital city. But if the article is omitted, the city is merely any city in Samaria. Besides the support of the manuscripts, the presence of the article also fits to the intention of Luke in mentioning Samaria about a region or district. ${ }^{73}$ Thus the option is limited to either the capital city or a certain significant region or district in Samaria. Luke likely recalls the commandment of Jesus in Acts 1:8 that his disciples will be his witness in Jerusalem, all Judea, Samaria, and until the end of the earth. ${ }^{74}$

A city that could represent the Samaria region must be significant in religious influence, although the population or the size should also be

the Apostles: A Commentary, trans. by Bernard Nobel and Gerald Shinn (Philadelphia: Westminster Press, 1971). For a helpful discussion on the source in this specific passage see Haar, Simon Magus, 73-76.

72 See the literal translation section I in this chapter 3 for the textual variant of this phrase and the support to maintain the article's presence.

${ }^{73}$ See for instance Luke 9:51-5; 10:25-37; also, Johnson, The Acts of the Apostles, 145; Barrett, The Acts of the Apostles, 402; Also Matin Hengel, "The Geography of Palestine in Acts" in The Book of Acts in Its First Century Setting vol. 4, ed. Richard Bauckham (Grand Rapids: William B. Eerdmans, 1995), 70.

${ }^{74}$ See Gaventa, The Acts of the Apostles, 136; Darrell L. Bock, "A Theology of LukeActs" in A Biblical Theolgy of the New Testament, edited by Roy B. Zuck, Darrell L. Bock \& Dallas Theological Seminary, Chicago, IL: Moody Press, 1996, 94. 
considered. Scholars ${ }^{75}$ have proposed four cities as Sebaste, Gitta, Sechem, and Sychar. The last one, Sychar proposed by Hengel is interesting particularly when the religious significance is underlined. His argument on the close distance of Sychar with Mount Gerizim as the religious centre of the Samaritan is convincing.

In verse 5-8, the crucial episode is verse six with its main point lies in the verb "kept on paying attention". ${ }^{76}$ The articular infinitive introduced by the preposition "in" clarifies that they pay attention after they hear and see the signs Philip keeps on performing. The hearing of Samaria's people refers implicitly to Philip's message about Christ. Thus, it is significant to notice that the paying attention of Samaria's people is caused by both Philip's message about Christ and the miraculous signs Philip performed that confirmed his message. However, the emphasis is likely put more on the signs as evident in verse 7 . The signs are certainly the miraculous works visible to the people of Samaria. First is the unclean spirit's exorcism, which signals the battle between God's power and Satan's. ${ }^{77}$ This seems to anticipate the confrontation between God's power and magical power in the story of Simon in section II. ${ }^{78}$

Second is the healing of many who have been paralyzed ${ }^{79}$ and the lame. All the signs Philip performed implicitly reveal that God's power is behind all his deeds. The silence regarding who Philip is may mean that Philip is mere "a servant of the word" as Luke perceived. ${ }^{80}$ The result of Philip's performance of God's power is concluded in verse eight that

75 See for instance Gaventa, The Acts of the Apostles, 136; Dunn, The Acts of the Apostles, 108; Barrett, The Acts of the Apostles, 402-3; Marshall, The Acts of the Apostles, 154; Martin Hengel, "The Geography," in Bauckham, 70-6. Gaventa and Barrett believe that Sebaste is referred, Dunn proposes Sechem, while Hengel accepts Sychar as the city. Marshall inclines to focus on the story though also provide three possible cities: Sebaste, Shechem, and Gitta.

76 This imperfect tense "paying attention" occurs three times in this pericope. The other twice belongs to Simon. For the meaning of imperfect tense see the discussion in the translation and grammatical examination of section I.

77 See Gaventa, The Acts of the Apostles, 136; also, Johnson, The Acts of the Apostles, 146.

${ }^{78}$ Ibid., 136.

79 The perfect passive of the participle "paralelumenoi" suggests that there is a causer of such a paralytic.

${ }^{80}$ For Luke 1:2 even the eyewitnesses of Jesus are understood as merely the servants of the word. In Acts the true actor behind the scenes is God. See Steve Walton, "The Acts - of God? What is the 'Acts of the Apostles' all about?" Evangelical Quarterly 80, no. 4 (October 2008): 291-306, who convincingly argued that God is the real actor in the book of Acts to support the apologetic purpose of Acts. 
there is much joy in that city. The phrase "in that city" strongly suggests the escalation of reception from merely "they" to "that city" which most probably means the entire inhabitant. By referring to "that city" Luke has hinted the spread of the gospel is fulfilling Acts 1:8. ${ }^{81}$

A critical question in this section is why Samaria's people seem very enthusiastic in welcoming Philip's message about Christ? Although Luke does not explain, still several reasons can be involved. The expected figure of "Taheb" (restorer) among the Samaritans can serve as one reason. When Philip's comes with the message about the Messiah (the Christ) the Messiah probably fits to the figure of "restorer". Another reason is that the miracles Philip performed are an apparent and visible exhibition of restoration experienced by many people in Samaria. Does this "restorer" prompt Luke to use the word "Christ" instead of Jesus? The answer is speculative since the text is silent. All three reasons may answer the question of why Samaria's people seem to pay attention to Philip's message immediately. Since the text is silent about the cultural context, it is better to list these three reasons as mere possibilities.

The combination of "paying attention", the miraculous signs, and the person of Philip foreshadows the coming figure of Simon. The "paying attention" occurs in the narration of Simon, even twice, while the miraculous signs also occur in Simon's narration but in a negative term, magic. Moreover, the claim of Simon seems to be very comparable to the "saying" of Philip.

The conclusion in verse eight represents the positive reception of the gospel Philip had preached. The much joy occurring in the city is a more positive term than the "amazement" caused by Simon. Once again, "in that city" implies that nothing can resist the reception of the gospel. Thus, this conclusion may implicitly serve as an introduction link to the account of Simon in the following section since he was one of those in that city.

Section II: Acts 8: 9-13

In section II the main character is Simon while the location remains the same, Samaria. The verb "proupêrchen" literally means existed before, thus suggesting that this is a flashback to Philip's account. ${ }^{82}$ The

${ }^{81}$ See Barrett, The Acts of the Apostles, 404.

82 See Johnson, The Acts of the Apostles, 146. 
disposition of the story of Simon separately from the account about Philip is because Luke intended to highlight Simon and the confrontation between God's power and magic as represented by Simon. ${ }^{83}$ Where does Simon come from is likely insignificant to Luke since his primary concern is Simon's identity associated to his works which is negatively depicted. However, questioning who Simon is, will help better understand the seriousness of the confrontation between Philip, Peter and John and Simon.

Simon's magical works and his influence are recorded in the extrabiblical writings. Simon is far more than merely an extraordinary person indeed he is a great person due to his tremendous influence in history. ${ }^{84}$ In contrast he is interpreted negatively by Christianity due to his magic. The Bible provides facts about Simon, but they are limited to his magical performance and self-exaltation. The record of Simon can be traced back in the writings of the church fathers such as Justin Martyr, Irenaeus, and Hippolytus. ${ }^{85}$ The significant of Simon is recognized by the report of Justin Martyr about Simon's journey to Rome during the reign of Emperor Claudius and won many followers using his magic. Justin reports that the Roman Empire erected a statue of Simon to honour him. ${ }^{86}$ Such an honoured statue must imply that Simon is a great and yet influential person in the Roman culture. One factor that makes Simon very influential is surely his magic and the principles behind the magic. The principles behind his magic remain long after Simon's death and can be identified by the presence of the Simonians (Simon's followers) whose doctrines were reported by a third century church father Hippolytus of Rome (170-235 AD) in his work "Philosophumena". ${ }^{87}$ Hippolytus

${ }^{83}$ See the structure in the outset of this chapter 3.

${ }^{84}$ Simon's influence exists even until now as evident in the term "simony" which means an act of selling church office and roles. This word simony is originated in his name, Simon the magician who desires to buy the Holy Spirit with his money.

${ }^{85}$ There are other writings in the apocrypha such as Acts of Peter, Acts of Peter and Paul, and Pseudo-Clementine literature that provide information about Simon, but since these writings are considered incredible, they are excluded from the discussion.

${ }^{86}$ See Justin, Apology I.26; Irenaeus, Adversus Haereses I 23; also, Eusebius, Church History II, 13. The report of Justin Martyr about Simon is not accepted by all scholars. Some doubt the credibility of the report. For the discussion on this subject, see chapter I under the subtitle "Magic and Religion".

87 See Hippolytus of Rome, Philosophumena, vol.l, ed. W. J. Sparrow, W. K. Lowther Clarke, trans. F. Legge, (New York: MacMillan, 1921), 36 ff. The "Against All Heresies" is also called "the Elenchus". In his writing, Hippolytus mentions pagan beliefs and 33 gnostic teachings which are heretic. 
provides extensive quotations from "Great Revelation" which the author is believed to be Simon Magus. With such records about Simon, it is obvious that the confrontation with Simon is very serious and critical since it involves a great power of magic which is real and tangible at the time.

Verse nine through eleven provides the biblical information on who is Simon. Two participles "keeps on practicing magic" 88 and "keeps on amazing the nation of Samaria"89 are used to depict the works of Simon. The existence of Simon lies in the magic he used that amazed the people of Samaria, ${ }^{90}$ since there are Luke reports no other works of Simon. It is important to notice that from the grammatical examination section II, it is Simon magic and not his self-exaltation saying that the people of Samaria amazes and pay their attention and then they exclaim that Simon is the power of God..$^{91}$ Two results come out of the magic Simon practised: First, the self-claim Simon made that he is someone great. Second is the fact that all from the small to the great were "paying attention". The negative image of magic is disclosed through the claim Simon made for himself. The arrogant self-saying of Simon as someone great is intensified by the saying of all that Simon is true "the power of God which is being called great". The recognition of Simon as "the power of God" and the two repetitions of "great" highlight the great power of Simon's magic.

The way Luke portrayed Simon is likely intended to demonstrate a sharp contrast with Philip. On the one hand, Philip is depicted positively to lead people to Christ. Philip's work involves miraculous signs, and his saying is about Christ and the power of Jesus' name. On the other hand, the portrait of Simon is negative. Simon's work is magic, and magic always carries with it a negative connotation. The twice repeated saying is that Simon is the great power of God, but the reference of God in such a saying is a certain divine being (or even many divine beings) that can

${ }^{88}$ The participle "practising magic" is used here.

${ }^{89}$ The word "amaze" occurs three times in this section. Two times intensify the amazement of Simon while the third time is to show the irony of Simon who used to amaze people but now, he himself is amazed by Philip's signs.

${ }^{90}$ See Barrett, The Acts of the Apostles, 406, who contended that the two participles "mageuôn" and "exsistanôn" are supplementary or even adverbial to the verb "proupêrchen" (exited before).

${ }^{91}$ This is contra to the notion of Haar that Simon, just as Philip, gets the attention from Samaria's people because of his saying; see Haar, Simon Magus, 167-9. 
be manipulated to perform magic and not the true God who corresponds to Jesus Christ, the Lord. A divine being alien to the true God is surely wicked. Finally, the result of Simon's magic cannot rival the signs of God and the power of Jesus' name.

The confrontation between God (and Christ) and magic is implicitly disclosed in the conquering of Simon who turns to believe and is amazed at the signs Philip performs. Twice the word "amaze" is associated with the work of Simon and his claim of great power, but now, he is the one who believes and is amazed at the signs and great power Philip demonstrates. This statement is full of irony. The following table 1 shows the contrasts more lucidly.

Table 1. The sharp contrast of Philip and Simon

\begin{tabular}{|c|c|c|c|}
\hline Verse & Philip & Simon & Verse \\
\hline & Work (positive) & Work (negative) & \\
\hline 6,13 & Signs which he keeps on & Practicing magic & 9 \\
\hline 13 & $\begin{array}{l}\text { doing (perform) great power } \\
\text { of God }\end{array}$ & With magic & 11 \\
\hline & The saying (to God, positive): & The saying (to self, negative): & \\
\hline 5 & Proclaim Christ & Saying great of self & 9 \\
\hline 6 & The words (about Christ) & Self-claim of the great power & 10 \\
\hline
\end{tabular}

Section III: Acts 8: 14-17

Peter and John arrive from Jerusalem to observe what is happening in Samaria. Scholarly discussions attempt to harmonize the lack of the Holy Spirit in the baptism Philip had done with the presence of the Jerusalem apostles to pass on the gift of the Holy Spirit to those who had been baptized in Jesus' name. In the grammatical examination section III, the word "only" may carry the sense of lacking something that is likely the receiving of the Holy Spirit. It has been widely understood that Luke intended to ensure the continuity of the "Hellenist" Philip and the Apostles in Jerusalem. ${ }^{92}$ However, the key element to solve the dispute is the receiving of the Holy Spirit since the following episode presents the

92 See Dunn, The Acts of the Apostles, 11l; He moves further to say that "Luke knows no silent comings of the Spirit," moreover this manifestation "could validate the major step forward." For a more discussion on this issue see Barrett, The Acts of the Apostles, 409-13. Gaventa in The Acts of the Apostles, 138 declines the contention of Fitzmeyer that this section is about to approve Philip's work. 
implicit power of the Holy Spirit who through Peter, rebukes Simon and reveals his wickedness heart extensively. While the continuation of Philip with Jerusalem may remain true, there is probably a more important issue Luke intended to foreshadow, the escalation of the negative image of Simon, the magician revealed by the Holy Spirit through Peter. ${ }^{93}$

A very significant occurrence in this section III is that the Holy Spirit is a gift, and a prayer is uttered prior to the dispensing of the Holy Spirit. So, any attempt to buy the Holy Spirit as Simon demonstrates is then intolerable and wicked because such attempts turn the Holy Spirit into an object to be manipulated rather than a subject that empowers the believers. Section III confirms the hint Luke had given in verse 13 that magic is a wicked power. Also, Simon keeps on being amazed that he keeps on looking at the signs and the great power Philip had performed rather than being a true believer. Therefore, Luke hints at the wickedness of magic which he will demonstrate afterwards.

The mentioning of the Holy Spirit must be understood in the context of section II as contrasting with the term "great power". Thus, the Holy Spirit which is given through the laying on of Peter's hand is intended to reveal the wickedness of magic that attempts to obtain the authority to control God's power. Just as Simon observes Philip obtain his power, he observes Peter's action to obtain the power to dispense the Holy Spirit. The continuous laying on of Peter's hand is evident in the use of the imperfect tense in Greek. This continuous action will give Simon enough time to observe prior to the offering of his money for the authority to master the Holy Spirit.

\section{Section IV: Acts 8: 18-24}

The way of giving the gift of the Holy Spirit so fascinates Simon that he offers money (silvers) to obtain the power. The offering of his money to obtain the authority to bestow the Holy Spirit implies that again he wants to use his magic to obtain profit for himself. It could be that he used to buy the authority to perform magic and charge people for

${ }^{93}$ See Dunn, The Acts of the Apostles, 11l; Gaventa, The Acts of the Apostles, 138 who also points out correctly that verse 20 has sharply overturned the conclusion of approving Philip's work; also, Barrett, The Acts of the Apostles, 412 with a slightly different emphasis. 
any magical performances. ${ }^{94}$ Simon's offering of money discloses several implications. First, his baptism is evidently a fraud. It is only a camouflage used to approach Philip and observe Philip's power and later the apostles and to offer money to obtain the authority over the Holy Spirit. Second, his baptism never represents his repentance. Simon is still a magician with the wicked magical principle of manipulating the divine being for his own sake. Simon's thought to buy the power of the Holy Spirit confirms this wicked principle. Third, consequently Simon never experiences the joy of Samaria's people; instead, his heart is bitter and unrighteous. The rebuke of Peter reveals the truth of the third implication. All these explain why Simon is interested only on the miraculous performance rather than to believe and submit to Jesus.

The rejection of Simon's money and even Simon himself for his desire with obtain the gift of God is consistent to the claim of Peter in Acts 3:6. Money has no part in receiving spiritual gifts. ${ }^{95}$ It is clear for Peter that the attempt to buy the gift of God $^{96}$ is a serious violation of the authority of God. The consequence of such a serious violation is destruction or death as described in verse 20. The rebuke of Peter in verse 21 is addressed to two issues: First, Simon has no share at all in this matter. ${ }^{97}$ Second, Simon's heart is not straight before God. Peter points to Simon's heart, the centre from which all the wickedness comes.

The presence of the particle "therefore" in verse 22 indicates a conclusion to Peter's rebuke. The repentance and prayer to the Lord for Simon's serious violation of God's authority is expected from him, but the episode does not inform Simon's response. The reason to repent is because of bitterness and unrighteousness in Simon. It is likely that Peter saw the state of Simon's heart. ${ }^{98}$ The response of Simon to ask

${ }^{94}$ See Barrett, The Acts of the Apostles, 413.

95 See Barrett, The Acts in the Apostles, 414 who provides support of the condemnation over "the use of spiritual gift for money making."

${ }^{96}$ It is likely that the genitive of source or belonging is employed. Thus, it is a gift that is from God. It is certain that this gift refers to the bestowing of the Holy Spirit as in Barrett, The Acts of the Apostles, 414.

${ }_{97}^{97}$ Two proposals are given to the understanding of the term "word / matter"; it is about the bestowal of the Holy Spirit of Christianity. So, Simon has no part in the bestowal of the Holy Spirit or in Christianity. Both are possible, but in term of the previous context in verse 18-20, it is likely that the bestowal of the Holy Spirit is the meaning. See Barrett, the Acts of the Apostles, 414-5.

${ }^{98}$ See Dunn, The Acts of the Apostles, 112 who contended that this is the apostate of Simon, but Barrett in The Acts of the Apostles, 417 declines to see this as a sin of Simon. 
Peter to pray for him imply that the evilness of Simon is still bound to his seeking of magical powers. Luke is clear that magic has been conquered. Therefore, the primary attention is then the spread of the Gospel as evident in the positive report in verse 25. Table 2 shows the contrast between gospel and magic throughout Acts.

Table 2. The contrast between Gospel and magic in Acts.

\begin{tabular}{|c|c|c|}
\hline Passage & Miracles or signs of Gospel & Magic (the magician) \\
\hline $\begin{array}{l}\text { Act 8:4-25 } \\
\text { (Simon - the } \\
\text { magician) }\end{array}$ & $\begin{array}{l}\text { - Confirm to the power of Gospel } \\
(4-6) \\
\text { - Lead to believe Jesus not the } \\
\text { sign doer } \\
\text { - Deliver human's afflictions } \\
\text { - Result: joy (in heart), be } \\
\text { baptized and receive the Holy } \\
\text { Spirit } \\
\text { - Nature: God's gift, redemptive, } \\
\text { unable to learn }\end{array}$ & $\begin{array}{l}\text { - Manipulates of divine } \\
\text { beings } \\
\text { - Leads to the magician } \\
\text { - Obtain self- } \\
\text { exaltation as divine } \\
\text { - Result: bitterness \& } \\
\text { bound to } \\
\text { unrighteousness in } \\
\text { heart } \\
\text { - Nature: Learnt, } \\
\text { bribable and } \\
\text { deceptive }\end{array}$ \\
\hline Act 13:6-12 & - Lead to believe the word of God & - Deceitful \\
\hline $\begin{array}{l}\text { (The case of } \\
\text { Proconsul }\end{array}$ & $\begin{array}{l}\text { - Lead to the Lord's straight path } \\
\text { (11-12) }\end{array}$ & $\begin{array}{l}\text { - Pervert the way of } \\
\text { the Lord }\end{array}$ \\
\hline Sergius Paulus) & $\begin{array}{l}\text { - Result: astonish to the teaching } \\
\text { of the Lord }\end{array}$ & $\begin{array}{l}\text { - Associated with evil } \\
\text { - Full of } \\
\text { unrighteousness }\end{array}$ \\
\hline $\begin{array}{l}\text { Act 19:10-17 } \\
\text { (The miracle of } \\
\text { Paul's apron, the } \\
\text { Sons of Sceva) }\end{array}$ & $\begin{array}{l}\text { - Confirm to God's power (10-11) } \\
\text { - Lead to believe the word of God } \\
\text { - } \text { Power is recognized by the evil } \\
\text { spirit } \\
\text { - Resultl: deliver people affliction } \\
\text { (12) } \\
\text { - Result2: The exaltation of Jesus' } \\
\text { name }\end{array}$ & $\begin{array}{l}\text { - Attempts to } \\
\text { manipulate God's } \\
\text { power (13) } \\
\text { - Result: disintegration } \\
\text { \& ruination } \\
\text { - Manifests as exorcist } \\
\text { as well }\end{array}$ \\
\hline $\begin{array}{l}\text { Act 28:1-10 } \\
\text { (Malta's event) }\end{array}$ & $\begin{array}{l}\text { - Preceded by prayer (8) } \\
\text { - Manifestation of God's power } \\
\text { (9) } \\
\text { - } \text { Result: honour }\end{array}$ & $\begin{array}{l}\text { - Believe many divine } \\
\text { beings (verse } 4 \text { and } \\
6 \text { ) }\end{array}$ \\
\hline
\end{tabular}




\section{Implication}

The implication of this exegesis is prominent for church ministry or mission. Particularly in Luke's thought Darrell L. Bock stated clearly as "Spirit-enabled and Spirit-directed, the church took up the mission described in Luke 24:47 and carried it out from generation to generation". ${ }^{99}$ This is to say that the church's mission to proclaim the gospel to every generation with the direction and power of the Holy Spirit is a necessity and not an option. Life in Indonesia specifically and the world in general is full of beliefs in a spiritual divine being behind the life phenomena. Church mission is inevitable to face all these beliefs. It is in this context the application of this exegesis is relevant.

When proclaiming the gospel in a remote area particularly, we Christians must rely on the Holy Spirit's power to direct our spirit and enable and strengthen us to share the good news as demonstrated in this article. Facing difficulties is inevitable, however, by relying of the Holy Spirit we are to be aware of magical powers, the unseen divine power that tries to impede the spread of the gospel. In such cases, Christians must employ the power of the Holy Spirit by sharing the deliverance of sin in the name of Jesus to conquer the magical powers. Only when these powers have overcome the joy of the good news will be experienced. No human strength can overcome magic.

Preaching the gospel must be put under God's fulfilment of His promise because this is Luke's understanding both in his gospel and Acts. Bock once again stated right that the prologue to Acts speaks of the completion of God's plan in terms of times and seasons, a phrase that indicates a set schedule (Acts 1:6-7). ${ }^{100}$ Leading people to receive Jesus as Lord and Savior in their full awareness must be the purpose of evangelism. It is God will and he will fulfil his plan as he promised. The glory of spreading the gospel is to God because the power to overcome magic and to experience joy is from the Holy Spirit. It is the Holy Spirit's power that enables every Christians to overcome these magical powers in evangelism.

${ }^{99}$ See Bock, A Theology of Luke-Acts, 91

100 Ibid., 91. 


\section{Conclusion}

The grammatical examination and the exegesis demonstrate that magic as represented by Simon is wicked. The wickedness can be identified from the purpose of practising magic to amaze the people of Samaria and claim and gain recognition as the great power of God as demonstrated in section I and II. Moreover, in section III and IV, the wickedness of magic is obvious in the intention of Simon's heart to obtain the authority to control the Holy Spirit, the gift of God. The consequence of this very serious sin which is destruction or death affirms the wickedness of Simon's heart. Finally, the reply of Simon to the rebuke of Peter confirms the total victory over magic after the two confrontations with Simon. The positive report on the gospel's further proclamation is possible only after the victorious confrontation with magic.

As demonstrated in this paper that the wickedness of magic is obvious in two ways: First, the manipulating the divine being for selfexaltation. Second is the attempt even to buy the power of the Holy Spirit and used it to gain attention from the people. The Gospel, which is the good news of God's salvation through faith in Jesus as Lord and Savior followed with receiving of the Holy Spirit and the experience of joy is contrast to magic as presented in table 1 and 2 . Therefore, magic must be overcome in the mission of evangelism so that the Gospel can spread to all people throughout the world. Every Christian must rely only on the power of the Holy Spirit to overcome magic as demonstrated by Philip, Peter, and John. Many amazing phenomena today will distract human from God. Witnessing the gospel by believing Jesus Christ as Lord and saviour is the only way to overcome those amazing phenomena, therefore proclaim the true gospel that brings to joy in life is a necessity in Church ministry and mission.

\section{Bibliography}

Barrett, C. K. The Acts of the Apostles vol. 1: ICC. Edinburgh: T \& T Clark, 1994.

Bock, Darrell L. "A Theology of Luke and Acts." In ABiblical Theology of the New Testament, 88-167. Edited by Roy B. Zuck, Darrell L. Bock and Dallas Theological Seminary. Chicago, IL: Moody Press, 1994. 
Burke, Tony. "Cursing and the Apostle: The Fighting for Authority in Early Christianity." Forum, Third Series 8, no. 2 (2019): 81-107.

Conzelmann, Hans. Acts of the Apostles: A Commentary on the Acts of the Apostles. Translated by James Limburg. Minneapolis: Fortress Press, 1987.

Creswell, John W. Educational Research: Planning, Conducting, and Evaluating Quantitative and Qualitative Research, 4th ed. Boston, MA: Pearson Education, 2002.

Dunn, James D. G. The Acts of the Apostles. Valley Forge, Pennsylvania: Trinity Press International, 1996.

Dupont, Jacques. The Sources of Acts: The Present Position. Translated by Kathleen Pond. London: Darton, Longman \& Todd, 1964.

Eusebius. "Church History I." In Nicene and Post Nicene Fathers vol. 1: Eusebius: Church History, Life of Constantine the Great, and Oration in Praise of Constantine, edited by Philip Schaff and Henry Wace, 113-4. Peabody: Hendrickson Publishers, 1999.

Gaventa, Beverly Roberts. The Acts of the Apostles. Nashville: Abingdon Press, 2003.

Haar, Stephen. Simon Magus: The First Gnostic? Berlin: Walter de Guyter, 2003.

Haenchen, Ernst. The Acts of the Apostles: A Commentary. Translated by Bernard Nobel and Gerald Shinn. Philadephia: Westminster Press, 1971.

Han, Chandra. "Magic in Greco-Roman Era: A Historical Context for Magic in the Acts of the Apostles." Jurnal Jaffray 18, no. 1 (2020): 1935. https://doi.org/10.25278/jj.vl8il.398.

Hengel, Matin. "The Geography of Palestine in Acts." In the Book of Acts in Its First Century Setting vol. 4, edited by Richard Bauckham, 27-78. Grand Rapids: William B. Eerdmans, 1995.

Hippolytus of Rome. Philosophumena vol.l. Edited by W.J. Sparrow and W.K. Lowther Clarke. Translated by F. Legge. New York: MacMillan, 1921.

Irenaeus. "Adversus Haereses I." In Simon Magus: The First Gnostic? 118. Berlin: Walter de Guyter, 2003.

Johnson, Luke Timothy. The Acts of the Apostles Sacra Pagina. Minnesota: The Liturgical Press, 1992.

Juld, Rahel Jum and I Ketut Enoh, "Okultisme dalam Pelayanan Pastoral." Jurnal Jaffray 11, no. 2 (October 2013): 165-190. https://doi.org/10.25278/jj7l.vlli2.83. 
Justin. "Apology I." In the Catholic Encyclopedia Simon Magus. New York: Robert Appleton Company. Accessed April 18, 2015 from New Advent: http://www.newadvent.org/cathen/13797b.htm.

Kent, Benedict H. M. "Curses in Acts: Hearing the Apostles' Words of Judgment Alongside 'Magical' Spell Texts." Journal for the Study of the New Testament 39, no. 4 (2017): 412-440. https://doi.org/10.1177/0142064X17703296.

Lüdemann, Gerd. Early Christianity according to the Tradition in Acts: A Commentary. Minneapolis: Fortress Press, 1989.

Marshall, Howard I. The Acts of the Apostles: An Introduction and Commentary Tyndale New Testament Commentaries. Grand Rapids: William B. Eerdmans, 1980.

Mounce, William D. Basics of Biblical Greek $3^{\text {rd }}$ ed. Grand Rapids: Zondervan, 2009.

Parsons, Mikeal C. Acts: Paideia Commentaries on the New Testament. Grand Rapids: Baker Academic, 2008.

Robertson, A. T. Word Pictures in the New Testament 3 vols. New York: Harper and Brothers, 1930-1933.

Tarundeep. "Remedial Theology: An exploration into the factorsReligious conviction, mysticism, and wellbeing." Scholedge International Journal of Multidisciplinary and Applied Studies 2, no. 9 (2015): 11-16. https://doi.org/10.19085/sijmas.020903.

Walton, Steve. "The Acts - of God? What is the 'Acts of the Apostles' all about?" Evangelical Quarterly 80, no. 4 (October 2008): 291-306. http://www.biblicalstudies.org.uk/pdf/eq/2008-4_291.pdf.

Wallace, Daniel B. The Basics of New Testament Syntax: An Intermediate Greek Grammar. Grand Rapids: Zondervan, 2000. 